\title{
National Water-Quality Assessment Program - Cycle II Regional Assessments of Aquifers
}

by Wayne W. Lapham, Pixie A. Hamilton, and Donna N. Myers

In the second decade (or "Cycle II") of the U.S. Geological Survey's National Water-Quality Assessment (NAWQA) Program, a major focus is on regional assessments of ground-water quality conditions and trends. The assessments will evaluate those conditions and trends in 19 aquifers, most of which underlie multiple States (see map inside).

These regional ground-water assessments will build on NAWQA findings from 1991 to 2001 ("Cycle I") in 51 "Study Units" across the Nation. (Summary reports of findings from the Study Units are available online; see back page). Regional assessments will complement and extend the findings of the Study Units to fill critical gaps in our understanding of ground-water quality and flow over broad regions, and determine trends at sites that have been monitored for more than a decade. The assessments will increase our understanding of how natural features and human activities affect ground-water quality. For example, regional differences in climate, geology, land use, and other factors can lead to regional differences in water quality among aquifer systems. Such regional variations can be analyzed using the large data set from NAWQA's Cycle I.

Water-quality information in a regional context will be useful for regional monitoring councils,
States, and localities in addressing priority water-quality and drinking-water issues in their areas. For example, regional-scale analyses, models, and other scientific tools will help with extrapolating findings to unmonitored, comparable areas in other parts of the regions. Data sets from multiple States representing similar hydrogeologic settings can be used by States and localities to assess, protect and manage their water resources more cost effectively.

Other activities planned during Cycle II include regional assessments of streams and rivers; continuing national syntheses of information on pesticides, volatile organic compounds (VOCs), nutrients, and selected trace elements; and national topical studies of mercury, the fate of agricultural chemicals, effects of urbanization on stream ecosystems, nutrient enrichment, and the transport of contaminants to drinking-water wells (Gilliom and others, 2001; see back page for on-line sources of information about these activities and information).

\section{Selection of aquifers for assessment}

A total of 62 principal aquifers underlie the United States (U.S. Geological Survey, 2003); the 19 aquifers selected for regional assessment account for about 75 percent of the estimated withdrawals of ground water for drinkingwater supply.

Each of the regional assessments focuses on water-quality issues of concern within a particular aquifer, and addresses one or more general issues. The studies will vary in scope and complexity and will be implemented at different stages throughout Cycle II. New topics may be added as the studies progress.

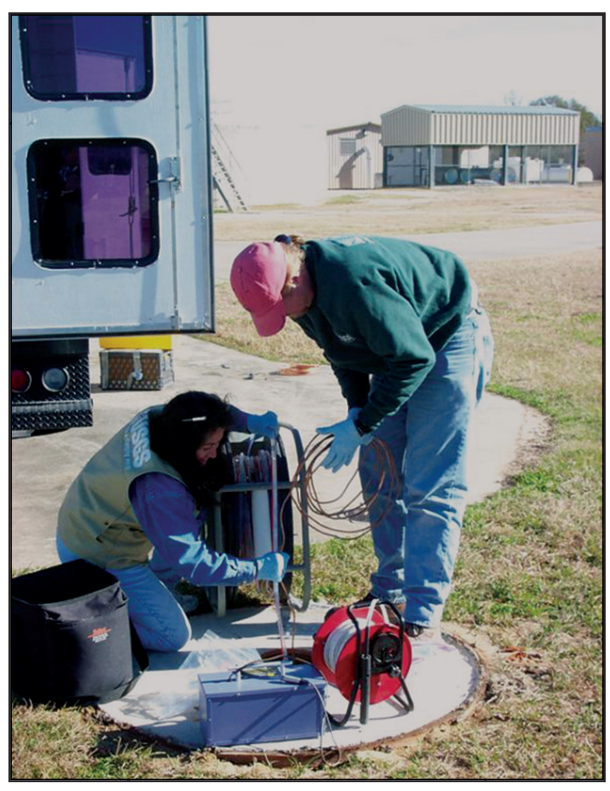

USGS personnel measure water levels and water quality in wells tapping major aquifers. 


\section{Nineteen aquifers selected for regional assessment}

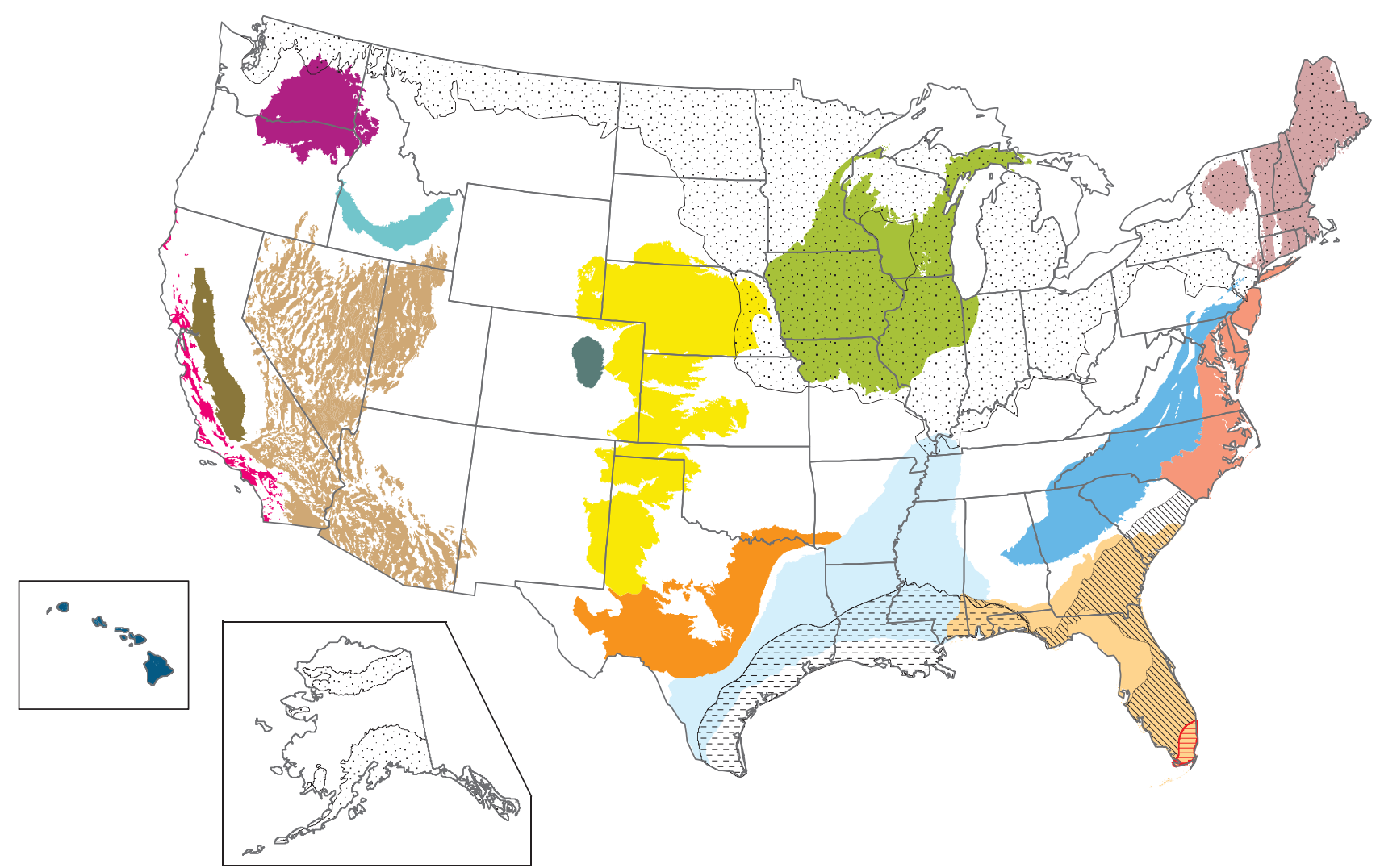

Source: Modified from U. S. Geological Survey, 2003

Hawaiian volcanic-rock aquifers

Aquifers composed of glacial deposits

California Coastal Basin aquifers

Central Valley aquifer system

- Columbia Plateau basin-fill and basaltic-rock aquifers ${ }^{1}$

- Snake River Plain basin-fill and basaltic-rock aquifers ${ }^{1}$

- Basin and Range basin-fill and carbonate-rock aquifers ${ }^{1}$

Denver Basin aquifer system

High Plains aquifer

Edwards-Trinity aquifer system

${ }^{1}$ Combinations of principal aquifers.

${ }^{2}$ Not considered principal aquifers (defined as regionally extensive aquifers or aquifer systems that have the potential to be used as a source of potable water). The New York and New England crystalline rocks are, in general, minimally permeable but contain locally productive aquifers that serve domestic supplies. 


\section{Regional assessments build on Cycle I findings}

Selected findings of NAWQA studies from 1991 to 2001 include:

- Contaminants in shallow ground water are widespread, often in mixtures but at low concentrations, across a wide range of landscapes and land uses.

- Concentrations of contaminants generally are lower in water in the deeper parts of the aquifers than in shallow ground water underlying agricultural and urban areas. Deep aquifers generally are more protected than shallow aquifers by relatively impermeable materials. Contaminants are most prevalent in aquifers where the geology allows water to move rapidly downward from the shallow ground-water system, such as in carbonate (karst) settings.

- Natural features-including soils, aquifer characteristics (such as geology, hydrology, mineral composition, and oxygen-reducing conditions), and the properties of the chemicals themselves (such as their tendency to dissolve, attach to sediment or bedrock, and persist in the environment)affect the movement of water and associated chemicals into and through the aquifer. For example, water and chemicals can move relatively rapidly into and throughout sand and gravel aquifers, alluvial fans, and carbonate settings with highly permeable sediment and open conduits in the bedrock.

- Contaminants found in ground water underlying agricultural and urban lands are closely related to the chemicals that are applied to the land. Nitrate and selected herbicides were frequently detected in shallow ground water underlying agricultural land, and VOCs were frequently detected in shallow ground water underlying urban land.

\section{Issues addressed by the regional assessments}

\section{Contaminants in aquifers}

Assessments of the occurrence of nutrients, pesticides, volatile organic compounds (VOCs), trace elements, and radionuclides are planned in, for example, the carbonate Biscayne and Floridan, the unconsolidated Surficial, the carbonate Basin and Range, the Piedmont, and the Hawaiian aquifers.

The occurrence of particular contaminants of concern will be assessed, such as arsenic and deicing chemicals in the glacial deposits aquifers; radon and uranium in the New York and New England crystalline rocks and glacial deposits underlying the Northeast and upper Midwest; salinity in aquifers underlying the Basin and Range and California Coastal Basins; and mixtures of urban pesticides in ground-water discharge from the glacial deposits, the Cambrian-Ordovician in the upper Midwest, and the New York and New England crystalline rocks in the Northeast.

\section{Water quality in domestic and public-supply wells}

The occurrence of anthropogenic chemicals, such as fertilizers and pesticides, in domestic and publicsupply wells will be assessed in aquifers that cover a large part of the Nation, including areas served by ground-water supplies from the Floridan, Northern Atlantic Coastal Plain, and the glacial deposits aquifers. Effects of long-term withdrawals (1950-2000) on ground-water quality in the Floridan aquifer system also will be assessed.

\section{Processes affecting water quality and contaminant transport}

Chemical and hydrologic processes that control the transport of contaminants will be assessed in the Northern Atlantic Coastal Plain, the glacial deposits, Basin and Range, and High Plains aquifers. In addition, studies will assess the effects on water quality of hydrologic alterations and controls - such as pumping, artificial recharge, and irrigation-in the High Plains, Hawaiian, Basin and Range, California Coastal Basin, and Central Valley aquifers.

\section{Effects of land use on water quality}

The relation of ground-water quality to land use will be examined in the Northern Atlantic Coastal Plain, Basin and Range, Central Valley, California Coastal Basin, High Plains, glacial deposits, and the Piedmont aquifers. Selected topics include the effects of chemical use and agricultural practices in four agricultural settings in Florida and the southeastern Coastal Plain; and effects on ground water used for drinking water from urban development in the Mississippi embaymentTexas coastal uplands and Piedmont aquifers. 


\section{A pilot regional assessment - the High Plains aquifer}

In 1999, NAWQA began a pilot regional assessment of the High Plains aquifer, which underlies an area of about 174,000 square miles in parts of eight states. Ground-water age in this aquifer ranges from less than 10 to more than 10,000 years. Studies through 2004 assessed spatial and temporal variability in water quality in the aquifer, including concentrations of nutrients, volatile organic compounds, pesticides, trace elements, and radon. Tritium and radiocarbon concentrations were used to assess ground-water ages and the timing of recharge to the ground-water system, and therefore, the vulnerability of the water to contamination from recent human activities.

Besides providing a broad assessment of water-quality conditions, the studies help us understand the factors that control the vertical transport of chemicals. A key finding was that chemical travel times through the thick unsaturated zone under irrigated farm fields ranged from about 50 to 375 years. These travel times suggest that it could be many decades before we can detect improvements in ground-water quality that result from implementing best-management practices on land.

Plans for 2005-06 include use of a USGS model to further assess ground-water quality and transport of chemicals.

Selected results from the High Plains studies are available online at $h$ ttp://co.water.usgs.gov/nawqa/ hpgw/HPGW_home.html.

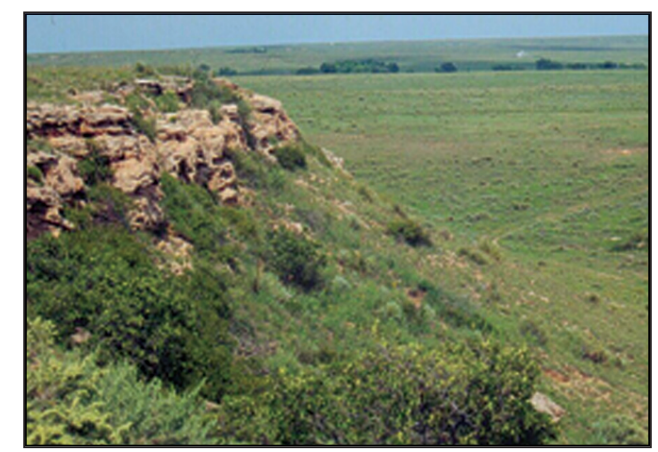

\section{How the study results can} be used

Resource managers and scientists can use the results of these studies in assessing the vulnerability of ground water to contamination across different regions. By identifying natural and human factors and processes affecting the occurrence and transport of contaminants, the assessments will allow managers and scientists to apply findings to broader classes of contaminants and to newly identified contaminants.

Regional-scale models and other decision-support tools, which integrate aquifer characteristics, land use, and water-quality monitoring data, will help water managers to assess conditions in unmonitored areas and the sustainability of water resources for future supply, as well as to develop cost-effective groundwater monitoring programs.

\section{References}

Gilliom, R.J., Hamilton, P.A., and Miller, T.L., 2001, The National Water-Quality Assessment Program-Entering a new decade of investigations: U.S. Geological Survey Fact Sheet 071-01, 6 p.

U.S. Geological Survey, 2003, Principal aquifers of the 48 conterminous United States, Hawaii, Puerto Rico, and the U.S. Virgin Islands, available online at http://www.nationalatlas.gov/mld/ aquifrp.html .

\section{For additional information about regional assessments of aquifers, contact:}

Wayne Lapham wlapham@usgs.gov (703) 648-5805

For online information, reports, and data from the NAWOA Program:

Summary reports of assessments conducted during the first decade in the 51 Study Units: http://water.usgs.gov/nawqa/ nawqa_sumr.html

Information and publications from the national synthesis teams:http://water.usgs.gov/ nawqal natsyn.html 